\title{
The use of transferable permits in transport policy
}

\author{
Charles Raux \\ Laboratoire d'Economie des Transports (Centre National de la Recherche Scientifique), ISH, 14 av. Berthelot \\ 69363 Lyon Cedex 07, France Email: charles.raux@let.ish-lyon.cnrs.fr
}

Published in Transportation Research Part D 9 (2004) 185-197

\begin{abstract}
This paper considers potential use of domestic transferable, or tradable, permit systems for the purposes of travel management, especially reducing environmental nuisances. The main arguments for and against the use of permits are analyzed. Secondly two case studies of existing permit systems are examined. The main conclusions are that tradable permits can address greenhouse gas and regional atmospheric pollutant emissions, and are suitable for congestion on a restricted time-space basis. Permits applied to mobile sources are technically feasible at acceptable financial cost for protecting sensitive geographical areas, and schemes applied to automakers for unitary vehicle emissions are also viable.
\end{abstract}

Keywords: domestic transferable permits, emissions reduction, mobile sources

\section{Introduction}

Local and regional airborne pollutants produced by automobiles can be harmful to human health. The continuous rapid growth in vehicle kilometers traveled (VKT) is tending to offset improvements in fuel quality and vehicle emission standards in most member states of the Organisation for Economic Cooperation and Development (OECD), and the rapidly growing use of older in developing countries is a major source of air pollution in urbanized areas of the developing world (Onursal and Gautam, 1997). In most industrialized countries the transport sector is one of the major greenhouse gases (GHG) emitters, particularly of $\mathrm{CO}_{2}$ (generating for instance $34 \%$ of $\mathrm{CO}_{2}$ in France in 1999 and $30 \%$ of $\mathrm{CO}_{2}$ in the US in 1997). Moreover, transport is the second highest growth sector in terms of GHG emissions in the OECD area, with its share of $\mathrm{CO}_{2}$ emissions increasing from about $25 \%$ in 1995 to $30 \%$ in 2020 (Organisation for Economic Cooperation and Development, 2000a).

Numerous synthesis studies have already considered how transport activity could be made less harmful to the environment (European Conference of Ministers of Transport, 1997; Organisation for Economic Cooperation and Development, 2000b). An important finding of this type of work is that transport emission reduction strategies should involve multiple technological, economic and societal measures, including slowing down the growth of VKT. Among the wide range of policy instruments available for managing transport activity, transferable (or tradable) permits (TPs) are attracting interest. However, although several proposals for the application of TPs in specific fields of transport have been made, there has hardly been any implementation.

\section{Why transferable permits in the transportation sector?}

The economic theory behind pollution permit markets can be traced back to the work of Coase (1960) on external costs, followed by that of Dales (1968) on regulating water use, and the formalization of pollution permit markets by Montgomery (1972). According to a general 
definition given by Godard (Organisation for Economic Cooperation and Development, 2001), transferable permits cover a variety of instruments that range from the introduction of flexibility into traditional regulation to the organization of competitive markets for permits. These instruments have in common: the setting of quantified physical constraints in the form of obligations, permits, credits or rights allocated to target groups of agents consuming scarce natural resources; and the permission granted to the agents to transfer these quotas between activities, products or places (offsetting), periods of time (banking) or to other agents (trading).

A system of transferable permits equalizes the marginal costs of reduction between all emission sources. Under certain assumptions this is a sufficient condition for minimizing the cost of achieving a given emissions reduction objective (Baumol and Oates, 1988). This result is obtained independently of the initial allowance of the rights, which makes it possible to separate the questions of efficiency and equity. However, Stavins (1995) has shown that when transaction costs are involved - the search for partners for the exchange, negotiation, decision-making, follow-up and compliance with the rules - the initial allocation of rights affects the final balance and the total cost of reducing emissions. The authorities may therefore attempt to reduce these transaction costs, for example by avoiding finicky regulations or by facilitating the activity of intermediaries between vendors and purchasers (Hahn and Hester, 1989; Foster and Hahn, 1995).

Use of transferable permits is not new. They have been used in the fisheries, and in the fields of construction rights and water pollution. The US 'Acid Rain' program experiment was developed to assess a large-scale system of tradable sulfur dioxide emission permits (Godard, 2000). An evaluation of these experiments makes it possible to identify the principal criteria of success for such systems and the associated legal and institutional pitfalls (Organisation for Economic Cooperation and Development, 1998).

Some of the features of permit systems make them particularly appropriate for the transport sector include (Organisation for Economic Cooperation and Development, 2001):

- In cases where a given environmental performance must be achieved in a context of uncertainty over agents' price response functions, a permit system is more likely to achieve a quantitative objective than taxation.

- In cases where agents are more sensitive to quantitative signals than price signals, particularly if the price-elasticity of demand is low in the short or medium term, a permit system is more appropriate.

- Permit systems allow flexible implementation of control policy and can, like road tolls, be used to target local and regional problems arising from transport activities.

- In political terms, systems where permits are allocated free of charge may be seen as a means of avoiding an additional tax, e.g. high fuel duties in Europe, this can enhance the acceptability of the new instrument.

- A quota system is the only type of system that allows distributive impacts to be treated separately from the 'efficient' allocation of efforts to reduce environmental damage.

Furthermore, an important feature of the effectiveness of TPs is the heterogeneity of the agents involved in the system. This means that the marginal costs of pollution abatement must be sufficiently different for agents allowing profits to be made by the exchange of permits and thus letting the market function effectively. 
The main arguments against the use of permits in the transport system are the cost of administration over a large number of mobile sources and the transactions costs of transferability.

The potential for implementation can be considered from several standpoints.

Appropriate nuisances. Two main criteria can be used to judge the appropriateness of transferable permit systems - the ability to impose a constraint, or a right, defined in a quantitative terms within a specified space and time, and the ability of agents to transfer all, or part, of these quantitative obligations. These criteria can be applied initially to the main nuisances associated with transport activity, i.e. regional pollution, greenhouse gas emissions, noise and congestion.

In many instances it is possible to set precise and measurable targets for aggregate emissions, as in the case of local air pollutants ${ }^{1}$ or greenhouse gases emissions. In all cases, it is the sum of the individual outputs of agents that produces the overall output. In contrast, this does not apply to something like noise that does not increase linearly with the number of individual emitters. It is also possible in many cases to establish space-time equivalents for aggregate nuisances: e.g., for regional air pollution for which permits can be traded within a geographical area and for greenhouse gas emissions where global trading is possible. Threshold effects may mean a quantity-based approach is required, as with greenhouse gas emissions, but it also applies to local air pollutant emissions when policy makers do not wish them exceed certain thresholds for health reasons.

Potential targets for TP implementation. Environmental impacts of transportation stems from

- the technical characteristics of vehicles (energy source, unitary consumption, emissions),

- the intensity of vehicle use (travel as a function of economic and social trends),

- the supply of transport infrastructure and services (price and quality of service for different modes of transport)

- land use (location of activities and its impact on distances traveled).

There is potential for controlling nuisances arising from transport in all these areas.

Unitary vehicle emissions. The sheer number of automobiles constitutes a basic obstacle to decentralizing permit systems. This is one reason why most proposals to decentralize permits have stopped at the level of automobile makers, and have been targeted at unitary vehicle emissions (Wang, 1994; Albrecht, 2000). This is where we find the most advanced use of permits.

Fuel standard. The US lead phase-down in gasoline is a case of the successful application of tradable permits to fuel quality standards. The lead rights trading program between refineries between 1982 to 1988 accelerated the phase-down of lead in gasoline until a complete ban came into effect in 1996. This case has been widely studied in the literature (Hahn and Hester, 1989, Kerr and Newell, 2001; Kerr and Maré, 1998; Nussbaum, 1992; Raux, 2002).

\footnotetext{
${ }^{1}$ Primary gases in the case of air pollutants. Secondary chemical reactions, such as ozone formation, are not considered.
} 
Car ownership. In 1990 a scheme of car-ownership rationing involving auctions of a limited number of certificates of entitlement to purchase a new car was initiated in Singapore. The number of certificates is determined each year on the basis of traffic conditions and road capacity and the certificates are issued each month (Koh and Lee, 1994). Chin and Smith (1997) showed control of ownership to be a useful instrument when automobile demand is inelastic and the social cost function is steep. Compared with price controls, quantity control reduces the welfare loss arising from any misperception of optimal equilibrium by the authority.

Car use. As an intermediate solution for controlling congestion. Daganzo (1995) proposed a congestion reduction scheme based on a 'hybrid between rationing and pricing'. This can be seen as a quota system, without the quotas being transferable. The system was modeled using the San Francisco Bay Bridge corridor by Nakamura and Kockelman (2002) who showed the difficulty of finding a combination of tolls and rationing rates which would benefit all groups of travelers. Other proposals involve setting quotas for VKT or trips within a given urban area for motorists that could be transferred among them, as an alternative to pure congestion pricing given the issue of acceptability (Verhoef et al, 1996; Marlot, 1998).

Land-use. In scattered settings, public transport is not suitable so longer distances trips are most often done by automobiles. This traffic is generally managed through regulation, however, there have been proposals for applying marketable permits to real estate developers on the basis of the travel volumes that their projects generate (Ottensmann, 1998).

For GHG emissions, targeting the fossil fuel consumption of end users with tradable permits seems to be the most decentralized incentive for reducing such emissions: end-users as the final decision-makers can modify their travel choices, activity locations, or choice of vehicle. However, political resistance to travel rationing may necessitate more indirect incentives (see Table 1).

Incentives to reduce unitary vehicle emissions are only one component of total travel consumption. The other component is VKT which could also be controlled by TPs but this has the same drawback of rationing travel as fuel consumption TPs, while being less optimally linked to GHG emissions. Controlling land use is in principle an attractive way of reducing distances traveled, but it is controversial - it has still not been proven that it is possible to reverse the tendency to travel longer distances by compacting locations again but, alternatively, the spatial concentration of activities yields more opportunities for cost-efficient transport alternatives that are less energy consuming. Car ownership is another indirect way of controlling car travel but the linkage with actual fuel consumption is very crude.

For regional pollutant emissions, the appropriateness of different targets is similar to the situation for GHG emissions. However, targeting fuel standards may be appropriate - they are, with less polluting engine combustion technologies, another way of reducing harmful tailpipe exhaust emissions per kilometer driven.

Regarding congestion, the most decentralized incentive is on end-user VKT (or even trips on specific corridors or through an area). Controlling land use may be an appropriate means of reducing congestion by reducing distances traveled, with the reservations already mentioned. Car ownership is also another, but merely indirect, way of controlling car use. 


\begin{tabular}{|l|c|c|c|c|c|c|}
\hline Nuisances & $\begin{array}{c}\text { Targets } \\
\text { or vehicle } \\
\text { technology }\end{array}$ & $\begin{array}{c}\text { Fuel } \\
\text { standards }\end{array}$ & $\begin{array}{c}\text { Car } \\
\text { ownership }\end{array}$ & $\begin{array}{c}\text { End user } \\
\text { VKT or trips }\end{array}$ & $\begin{array}{c}\text { End user fuel } \\
\text { consumption }\end{array}$ & Land use \\
\hline GHG emissions & $\mathrm{xx}$ & & $\mathrm{x}$ & $\mathrm{x}$ & $\mathrm{xxx}$ & $\mathrm{xx}$ \\
\hline Regional pollution & $\mathrm{xx}$ & $\mathrm{xx}$ & $\mathrm{x}$ & $\mathrm{x}$ & $\mathrm{xxx}$ & $\mathrm{xx}$ \\
\hline Congestion & & & $\mathrm{x}$ & $\mathrm{xxx}$ & & $\mathrm{xx}$ \\
\hline
\end{tabular}

From $\mathrm{x}=$ low to $\mathrm{xxx}=$ high level of appropriateness

Table 1: Appropriateness of TP targets for different nuisances

\section{TWO CASE STUDIES}

\subsection{Ecopoint program in Austria}

Ecopoint is a program for limiting pollution and noise from truck traffic passing through Austria. It involves quotas, but these are of the 'cap but no trade' type, since they are not transferable.

Through Austria pass the north-south route between Italy and Germany and one of the major links between countries of Eastern Europe and Western Europe. Austria's mountainous geography funnels north-south traffic into ecologically fragile Alpine valleys, notably the Brenner Valley. The morphology of these valleys is such that exhaust emissions cannot readily escape, and highway noise is intensified. The concentration of nitrogen oxides is three times higher than on a plain with similar traffic volumes (Commission of the European Communities, 2000).

Concern over this growing pressure on the environment led Austria to negotiate an agreement with the European Union (EU), with the aim of reducing noise and atmospheric pollution, mainly $\mathrm{NO}_{\mathrm{x}}$ emissions, produced by trucks passing through Austria. The agreement's initial objective was to reduce these emissions by $60 \%$ from 1991 over the 12 year life of the agreement.

The system of transit rights known as Ecopoints (Ökopunkte) applies to heavy goods vehicles (HGV) with a gross weight of more than 7.5 tons passing through Austria, whether loaded or empty. The scheme covers HGVs from all EU Member States and certain other countries that have signed agreements with Union. Since October 1, 1990, the unitary emissions of heavy vehicles are stated in an approval document produced at the time of manufacture. Each Member State must establish a Conformity of Production (COP) document for the vehicle, which states $\mathrm{NO}_{\mathrm{x}}$ emissions and the number of Ecopoints required to travel through Austria.

An Ecopoint corresponds to the emission of one gram of $\mathrm{NO}_{\mathrm{x}}$ per kilowatt-hour $(\mathrm{kWh})$. For example, a vehicle normally emitting 10 grams of $\mathrm{NO}_{\mathrm{x}}$ per kilowatt-hour will have to use 10 Ecopoints to cross Austria. There is a flat charge of 16 Ecopoints for vehicles manufactured before October 1, 1990, or that have no COP document. When a vehicle receives a new engine, it is given a new COP document.

Ecopoints quotas are distributed annually by the European Commission among Member States according to an allocation schedule established in the regulations and periodically revised by the Commission. Countries redistribute their Ecopoints which are valid for a year 
among their hauliers. The allocation schedule among states was based on their share of the traffic between the Community and Austria in 1991. In practice, Italy and Germany use twothirds of the Ecopoints, while the third largest user is Austria itself (15\%). The transfer of Ecopoints, then, does not involve any market. Transfer involves unused Ecopoints that are reallocated through an administrative process involving all participating states.

Ecopoints can be issued in paper format or electronically - the former requiring a border stop - which is consistent with abolition of internal border controls within the EU. The electronic system detects the vehicle with the aid of an onboard device. To minimize the cost of installing equipment, the device the haulier must purchase is very simple. The onboard electronic transponder ('Ecotag') identifies the haulier and the vehicle and contains details of its COP document. The Ecotag detects the passage of the truck across the border. Some 169 border crossings are equipped with overhead electronic readers. Information of the date, time and point of entry into Austria are recorded. These data permit inspection by mobile control units within the country. Upon leaving the country, the central system reads the Ecotag, debits the Ecopoints, transmits an electronic invoice to the haulier's country and notifies the authorities of any trip not covered by sufficient Ecopoints.

To avoid an excessive burden for occasional through trips the paper system can still be used. In practice, more than $95 \%$ of Ecopoints are handled electronically. It is estimated that half a million fraudulent Ecopoints are used each year (from a total of about 10 million allocated in 2002).

$\mathrm{NO}_{\mathrm{x}}$ emissions were targeted in order to encourage the use of increasingly cleaner trucks. A further objective was to reduce noise. To avoid a situation where $\mathrm{NO}_{\mathrm{x}}$ emissions might be reduced while allowing an increase in through traffic, a special quantitative limit on through trips, the so-called ' $108 \%$ clause', was imposed from the outset. If the number of through trips in any given year exceeds that of the reference year 1991 by more than $8 \%$, the number of Ecopoints distributed in the following year must be cut by $20 \%$ beyond the linear reduction already established.

Such a situation occurred in 1999, and sparked a dispute between Austria and other Member States. The Commission in 2000 settled the dispute by temporarily suspending enforcement of the clause. While hauliers fiercely object to the current system because of the ' $108 \%$ clause', the Austrian government backed by public opinion has persuaded the European Commission to consider extending the system to 2004: the number of Ecopoints would be the same as in 2003 (i.e. $60 \%$ of the 1992 level) and the ceiling of 108\% would be removed. This provision could be extended for two more years pending replacement by the proposal framework for infrastructure charging in the EU.

There is very little quantitative data available on the costs and benefits of the Ecopoint program. With regard to costs, one must consider that interoperable electronic road charging systems targeting trucks exist already, or are being set up in several European countries (operational in Switzerland since 2001 and in 2004 in Germany). Once these systems are in place the incremental cost of operating a truck traffic permit system should be low.

In terms of benefits, there has been a potential technology shift effect. The proportion of trucks paying 15 Ecopoints or more dropped from 51\% in 1993 to less than 2\% in 1999. On the other hand, the proportion of trucks paying 7 Ecopoints or less (EURO II) rose from $0.1 \%$ in 1993 to more than 78\% in 1999; the EURO III Standard applicable in 2000 corresponds to 
a maximum of 5 Ecopoints. Thus, the number of Ecopoints used by trucks has declined more swiftly than the target value laid down in the agreement.

Although it is impossible to say exactly what role the Ecopoints have played in this technological evolution, it is probable that the system has accelerated the impact of the program for tightening European emission standards.

On the other hand, the program's design has a number of shortcomings.

- Insufficient coverage of pollution sources. Most heavy-duty vehicles traveling in Austria do not pay Ecopoints, because they are traveling to or from points in the country; lightduty vehicles and buses are also excluded from the scheme;

- A lack of incentive to use even cleaner trucks. Now that low-emission vehicles are in production and are being used, the ' $108 \%$ clause' represents a hindrance to the development of lower-emission vehicles. In effect, using cleaner vehicles would only make sense if additional trips beyond the $108 \%$ could be made for the same number of Ecopoints, which is not the case.

- It is too comprehensive a measure for addressing the preservation of alpine valleys. The Ecopoint system applies to the entire whole of Austria and makes it possible for through traffic, and hence emissions to increase sharply in the alpine valleys as long as it is offset by reductions on the plains.

These shortcomings offer insights into the context in which a quota system targeting vehicular traffic may be applied and how it could be designed. The most efficient trade-off between administrative costs and benefits for a scheme aiming to protect a given region would involve minimizing the number of available entry points. Pollutant emissions are one possible target as in the Austrian case. Another possibility is to avoid excessive traffic growth that produces noise and diminishes road safety. The target would be the number of trips made or vehicleskilometers traveled within the area. Allowing the quotas to be transferred among hauliers on a market basis would reduce the total cost of this scheme. Options of including regional transport authorities, other transport mode operators such as railways, or multimodal funds, may be useful. This could encourage the use of the rail as an alternative for crossing the area. TP markets focused on geographic areas need the participation of operators of other modes such as rail to benefit from the heterogeneity of reduction costs and modify modal split.

\subsection{The ZEV program in California}

Despite the near elimination of the smog alerts in the Los Angeles, according to the California Air Resources Board (CARB) further efforts to reduce vehicle emissions are required (California Air Resources Board, 2001). Because of the forecast high growth in VKTs, further progress towards reducing pollutant emissions from gasoline-powered vehicles is likely to be limited. The genuine Zero Emission Vehicle (ZEV) with no tailpipe emissions, no evaporative emissions, no emissions from fuel production and handling (i.e. at the refinery or at point-ofsale), and no onboard emission control system that might deteriorate over time would be the electric vehicle.

The CARB has the authority to regulate emissions from road vehicles and other mobile sources, and is responsible for enforcing emission reduction measures adopted by the State of California. The first major drive towards a reduction in pollutant emissions from motor vehicles in California dates from the early 1990s. This relied on the principles of averaging permits applied to automakers' fleets, a policy measure of the same kind as Corporate Average Fuel Efficiency (CAFÉ) scheme introduced in 1978 at the federal level (Greene, 
1990). However the CARB added the objectives of stiffer enforcement of emission standards and the highly ambitious introduction of electric vehicles.

In 1994 the CARB instituted the LEV I (Low Emission Vehicle) program that was designed to enforce more rigorous emission standards and to give automakers greater flexibility in specifications for fuels, pollution control techniques and types of propulsion. The program established four categories of LEV - transitional LEVs (TLEVs), LEVs, Ultra LEVs (ULEVs) and ZEVs. Each is defined according to a maximum emissions level for hydrocarbons (NMOG, non-methane organic gases), carbon monoxide and nitrogen oxides. The NMOG index is the reference indicator reflecting total emissions of atmospheric pollutants.

Instead of requiring every vehicle sold to meet a single emissions standard, each automaker must conform to the standard on the basis of a weighted average of emission rates for its fleet. This is calculated by breaking down the fleet into the four categories of LEV and applying the maximum allowable emission rate to the number of vehicles sold in each category. The automaker can also earn credits if it exceeds the required standard, and can then sell or bank these credits, or it can purchase credits if its fleet does not meet the standard. Participating manufacturers have full freedom in negotiating credit transfers.

Finally, a minimum percentage of ZEVs had to be delivered for sale. The initial legislation required the 7 most important American and Japanese automakers to ensure that at least $2 \%$ of the vehicles they delivered for sale in California be ZEVs in 1998; this percentage was to rise to $5 \%$ in 2001 .

A manufacturer will have to comply with regulations by submitting a certain number of ZEV credits calculated annually on the basis of the emission standards of it's light-vehicle fleet. Any manufacturer failing to offer the required number of ZEVs, or to submit the required number of credits, will be subject to a fine. The fine of $\$ 5,000$ per non-conforming vehicle, applies to any manufacturer selling a new motorized vehicle not compliant with the state's emission standards. A maximum price for credits is then established, equal to the amount of the fine established in the regulations.

The automobile and oil industries, along with elected politicians, brought pressure to amend this legislation, resulting in the March 1996 memorandum of agreement. The CARB agreed to push back the 1998 deadline to 2003, but in return insisted that the ZEV share of sales should be increased to $10 \%$. Also, through voluntary agreements negotiated between the CARB and each of the large volume manufacturers, the latter undertook to produce a certain number of demonstration vehicles between 1998 and 2000.

The regulations were again amended in 1998 in recognition of the difficulties that automakers were having in producing low-cost ZEV vehicles, and the wide diversity of technologies available for further reducing emissions - in particular, hybrid electric vehicles and fuel cell vehicles. This LEV II program was given further flexibility, in the form of supplementary bonus ZEV credits for ZEVs available before the 2003 deadline, and partial ZEV (PZEV) credits that could be earned by producing 'very clean' but not strictly ZEV vehicles. On the other hand emission standards for all vehicle categories were lowered and Sport Utility Vehicles and pick-up trucks were included in the regulation. 
Underlying the added flexibility was the CARB's recognition that significant progress had been made in reducing emissions with a new category of vehicle with a conventional internal combustion engine - Super Ultra Low Emission Vehicles (SULEV). A SULEV certified to meet emission standards for 150,000 miles or 15 years (with a certified emission control onboard device) and to produce no evaporative emissions can apply for a PZEV credit, i.e. 0.2 $\mathrm{ZEV}$ credit. Because their operating range is greater than that of electric vehicles they have the potential for greater market penetration and for reducing emissions more quickly.

Nevertheless, since there can be no absolute guarantee against the deterioration of emission control mechanisms beyond 150,000 miles, the CARB issued restrictions on this mechanism for manufacturers selling more than 60,000 vehicles per year. They can meet their 2003 obligation with PZEV credits, but only up to $6 \%$ of the $10 \%$ ZEV mandate; the remainder must be achieved through sales of actual ZEVs. The remaining manufacturers subject to the ZEV regulation (intermediary manufacturers selling more than 10,000 vehicles/year) may meet all of requirement with PZEVs.

In introducing this, the CARB expected that manufacturers would turn to producing SULEVs as successors to ULEVs because the technological shift is less costly than a move to the electric ZEV that does not yet enjoy the same economies of scale as gasoline-powered vehicles. However, to mid-2002, only the Nissan Sentra CA (a SULEV), introduced in 2000, had been certified for PZEV credits.

The 2003 ZEV target was reconfirmed by the CARB in January 2001, but further amendments were introduced to reduce the cost of the program to manufacturers. The required number of pure ZEVs in the first years of the program was halved; the ZEV credit multiplier for pre-2003 ZEV sales was increased; the number of vehicles needed to obtain PZEV credits in the first years was reduced; and a new class of advanced technology PZEVs (AT-PZEV) was created, consisting of compressed natural gas, hybrid or methanol fuel cell vehicles that can satisfy up to half of the pure ZEV requirement (i.e. $2 \%$ within the $10 \%$ mandate in 2003). On the other hand, this mandate for ZEVs or equivalent credits is to be increased in gradual stages from $10 \%$ in 2003 to $16 \%$ by 2018 .

Our assessment relates to estimates of operating costs and the advantages expected from the program. The only cost specific to the credit scheme is the verification of the credits submitted by manufacturers. The other costs, such as measurement and monitoring of pollutant emissions, tracking new developments in engine and battery technologies, are an inherent part of any regulatory system. Hence, the incremental administrative costs represented by the credit program are fairly low.

However, the costs engendered by the accelerated market introduction of electric, hybrid or PZEV vehicles are another matter. Calculations by the California Air Resources Board, (2000a) of the incremental initial cost in 2003 of producing these vehicles, compared to the baseline SULEV vehicle, ranges from $\$ 7,500$ for a 'city EV' to $\$ 20,000$ for a freeway-capable $\mathrm{EV}$. Most of this incremental cost relates to batteries. By comparison, the incremental cost of a hybrid vehicle is $\$ 3,300$ and for a PZEV it is $\$ 500$. Only when volume production is reached will high-efficiency electric battery-powered vehicles achieve costs per mile comparable to those of hybrid vehicles or PZEVs.

During the period 1998 to 2000 covered by the 1996 agreement electric vehicles sold in California benefited from a buy-down grant of $\$ 5,000$ paid to the manufacturers, and financed 
in equally by the California Energy Commission and the local air pollution control districts. From 2000 to 2002 incentive funds amounted to $\$ 38$ million: grants for consumers purchasing a ZEV would therefore amount to $\$ 9000$ prior to 2003 and $\$ 5000$ after.

The expected benefits are long term, reflecting the time that will be needed for electric vehicles to achieve significant market penetration. The CARB (2000a) estimated reductions in direct and indirect vehicle emissions in the South Coast Air Basin by 2010 (including the production, processing, transport and distribution of fuel or electricity). Total emissions were estimated using different electric vehicle penetration scenarios, with a maximum of $10 \%$ by 2010. They show that the advantage in terms of air quality is fairly low compared to a base scenario in which no battery vehicles are sold. The maximum reduction is 1.91 tons of pollutant per day compared to total emissions of 25.45 tons per day in the base scenario. Only in a scenario where $50 \%$ of all vehicles on the road were ZEVs by 2020 would direct daily emissions be reduced by $30 \%$ at that time.

The program has, however, sparked intensive research and development efforts by federal agencies and private business, reflected in the filing of many patents: from 1982 to 1991 the number of patents relating to electric vehicle technology averaged about seven per year and was declining despite federal funding. Yet this rate rose to more than 50 patents in 1994, the year the LEV I program came into effect, and then to more than 80 per year between 1996 and 1998 (Burke et al, 2000).

It is difficult to say today whether the program is a success, because it is only now starting to take full effect. Prior to mid-2001, credit transfers were limited to meeting automakers' voluntary commitment to produce demonstration vehicles over the period 1998-2000 (e.g. the transfer of credits between Ford and Mazda).

\section{CONCLUSIONS}

The Ecopoint system has shown that it is technically possible to apply a quota-based system of permits to mobile sources within a defined area, at an acceptable financial cost. It therefore goes some way towards quelling objections that administrative costs of permit systems for mobile sources will be too high. However the region of application must be one where points of entry and exit are few and readily controllable. A trade-off has to be made between the number of points to be controlled and the size of the area affected.

The California ZEV program, although its impacts will only be felt in the future, shows the feasibility of a system of credits for unitary vehicle emissions that are tradable between automakers. Its incremental administrative costs are negligible compared to the normal expense of monitoring and enforcing regulations.

The need for clarity, simplicity and pragmatism for transferable permit programs in general has long been recognized - e.g., the gasoline lead phase-down program in the US (Hahn and Hester, 1989). The importance of clarity is reinforced by the analysis of Austria's Ecopoint program and California's ZEV program. In all cases, the physical basis is clearly defined grams of lead per gallon, grams of $\mathrm{NO}_{\mathrm{x}}$ per kilowatt-hour, and grams of NMOG per mile. Simplicity is also important for transactions if the advantages of trading are to be fully realized. This is the case with the lead phase-down and ZEV programs, where there are no 
needs for any regulatory authority to become involved in trading. This helps minimize transaction costs.

There have been failures with tradable permits. These can partly be explained by their complexity and involvement of regulators as observed in the implementation of water rights markets in California (Organisation for Economic Cooperation and Development, 1997) or the markets for water pollution rights on the Fox River (Hahn and Hester, 1989). In the first case too many parties had the right to veto proposed transactions, and in the second transactions had to be approved by the authorities after a complex appraisal process when potential purchasers had to prove their needs.

The pragmatism criterion relates to the design of the program: it should be able to evolve in response to discrepancies between its objectives and the adaptation costs borne by program participants. Good examples of such pragmatism can be found in the lead phase-down program, with its different trading and banking phases, and in the ZEV program, where changes to the credit formulas provide automakers with more opportunities to adapt. However, the Ecopoint program lacks such pragmatism and is, at least in its present configuration, in something of a crisis. If a program like this were to be established for the EU, any amendment would require agreement between Member States, that would be difficult to achieve given their divergent interests. Pragmatism is also only possible when the regulatory authority enjoys strong political support and has sufficiently broad powers, as with the ZEV program.

Authorities are often forced into a compromise between having the necessary flexibility to allow the permit system and its accompanying program of regulations to evolve, and the rigidity to ensure that the permit is of durable value in order to encourage transactions.

Regarding abatement costs, the allocation efficiency of taxation and permits is the same. Since fuel taxes are already in place, putting a $\mathrm{CO}_{2}$ tax on top of the existing tax would be less costly to administer for multiple mobile sources than a system of permits applied to those sources. However the 'tax revolt' that took place in several European countries in September 2000, when a sharp rise in oil prices further raised the price of gasoline, which was already highly taxed, shows the limits to public acceptance of significant further fuel tax increases (Lyons and Chatterjee, 2002). Moreover, the speed and the size of the most recent oil price increase in 1999-2000 suggest that the pre-tax price could collapse just as severely, as we have seen recently. This would completely wipe out the price effect of a carbon tax.

On the other hand, permits that are allocated free of charge are seen by agents as a means of avoiding an additional tax. Moreover agents selling their unused permits receive an immediate and tangible monetary benefit. On these grounds free of charge permits are potentially more acceptable than new taxes. For this reason new approaches for the decentralization of permits in the transportation sector as a possible alternative to $\mathrm{CO}_{2}$ taxation ${ }^{2}$ would be worth exploring.

\footnotetext{
${ }^{2}$ Such a system has been designed for a domestic implementation in France by Raux and Marlot (2001).
} 


\section{ACKNOWLEDGEMENTS}

This paper has benefited from comments made by those taking part in the OECD Informal Experts Workshop on Domestic Tradable Permits in September 2001 and subsequent anonymous reviewers.

\section{REFERENCES}

Albrecht, J., 2000. The diffusion of cleaner vehicles in $\mathrm{CO}_{2}$ emission trading designs. Transportation Research Part D, 5:385-401.

Baumol, W. and Oates, W., 1988. The Theory of Environmental Policy. Cambridge University Press, Cambridge.

Burke, A.F., Kurani, K.S. and Kenney, E.J., 2000. Study of the Secondary Benefits of the ZEV Mandate. Report for the California Air Resources Board. Institute of Transport Studies, University of California, Davis.

California Air Resources Board, 2000a. Staff Report. 2000 Zero Emission Vehicle Program Biennial Review. CARB, Sacramento.

California Air Resources Board, 2000b. Secondary Benefits of the Zero-Emission Vehicle Program. Research Division. CARB, Sacramento.

California Air Resources Board, 2001. Staff Report. Initial Statements of Reasons. CARB, Sacramento.

Commission of the European Communities, 2000. Report from the Commission to the Council on the Transit of Goods by Road through Austria. COM(2000) 862 final. Brussels.

Chin, A. and Smith, P., 1997. Automobile Ownership and Government Policy: The Economics of Singapore's Vehicle Quota Scheme. Transportation Research Part A 31: 129-140.

Coase, R., 1960. The problem of Social Cost. Journal of Law and Economics, 3: 1-44.

Daganzo, C.F., 1995. A Pareto Optimum Congestion Reduction Scheme. Transportation Research B, 29:139-154.

Dales, J.H., 1968. Land, water and ownership. Canadian Journal of Economics, 1: 797-804.

European Conference of Ministers of Transport, 1997. $\mathrm{CO}_{2}$ Emissions from Transport, ECMT Paris.

Foster, V. and Hahn, R., 1995. Designing more efficient markets: lessons from Los Angeles Smog Control. Journal of Law and Economics, 38:19-48.

Friedman, D., Wright, J., Sperling, D., Burke, A. and Moore, R., 1998. Partial ZEV Credits. An Analysis of the California Air Resources Board LEV II Proposal to Allow NonZEV's to Earn Credit Toward the 10\% ZEV Requirement of 2003. Institute of Transport Studies, University of California, Davis.

Godard, O., 2000. L'expérience américaine des permis négociables. Économie Internationale 82: 13-43.

Greene, D.L., 1990. CAFE or PRICE? An analysis of the effects of federal fuel economy regulations and gasoline price on new car mpg, 1978-89. The Energy Journal: 11.

Hahn, R. and Hester, G., 1989. Marketable permits: lessons for theory and practice. Ecology Law Quarterly, 16:361-406.

Kerr, S. and Maré, D., 1998. Transaction Costs and Tradable Permit Markets: The United States Lead Phase-down. Working Paper, Motu Economic Research, Wellington

Kerr S. and Newell, R., 2001. Policy-Induced Technology Adoption: Evidence from the US Lead Phase-down. Discussion Paper 01-14. Resources for the Future, Washington.

Koh, W.T.H. and Lee, D.C.K., 1994. The vehicle quota system in Singapore: an assessment. Transportation Research Part A 28: 31-47. 
Lyons, A. and Chatterjee, K. (eds) 2002. Transport Lessons from the Fuel Tax Protests of 2000. Ashgate, Aldershot.

Marlot, G., 1998. Réguler la congestion par des permis négociables: une solution au dilemme efficacité/acceptabilité. 8th WCTR, Antwerp..

Montgomery, W.D., 1972. Markets and licenses and efficient pollution control programs. Journal of Economic Theory, 5: 395-418.

Nakamura, K. and Kockelman, K.M., 2002. Congestion pricing and road space rationing: an application to the San Francisco Bay Bridge corridor. Transportation Research Part A, 36: 403-417.

Nussbaum, B.D., 1992. Phasing down lead in gasoline in the US: mandates, incentives, trading and banking. In Jones, T. and Corfee-Morlot, J. (eds) Climate Change: Designing a Tradable Permit System. OECD, Paris.

Organisation for Economic Cooperation and Development, 1997. Putting Markets to Work. The Design and Use of Marketable Permits and Obligations. OECD, Public Management Occasional Paper 19, Paris.

Organisation for Economic Cooperation and Development, 1998. Lessons from Existing Trading Systems for International Greenhouse Gas Emissions Trading. OECD Environment Directorate. Paris.

Organisation for Economic Cooperation and Development, 2000a. Environmental Outlook, Draft, OECD, Paris.

Organisation for Economic Cooperation and Development, 2000b. Environmentally Sustainable Transport. Futures, Strategies and Best Practices. Synthesis report, OECD, Paris.

Organisation for Economic Cooperation and Development, 2001. Domestic Transferable Permits for Environmental Management. Design and Implementation. OECD, Paris.

Onursal, B. and Gautam, S.P., 1997. Vehicular Air Pollution. Experiences from Seven Latin American Urban Centers. World Bank Technical Paper 373. World Bank, Washington.

Ottensmann, J.R., 1998. Market-based exchanges of rights within a system of performance zoning. Planning and Markets, 1.

Raux, C., 2002. The use of transferable permits in the transport sector. In OECD (ed), Implementing Domestic Tradable Permits. Recent Developments and Future Challenges. OECD, Paris.

Raux, C. and Marlot, G., 2001. Transport et effet de serre: un système de permis négociables appliqué aux automobilistes. Transports,407: 157-164.

Stavins, R., 1995. Transaction costs and tradable permits. Journal of Environmental Economics and Management, 29:133-148.

Verhoef, E., Nijkamp, P. and Rietveld, P. 1996. Tradable permits: their potential in the regulation of road transport externalities. Tinbergen Institute, Amsterdam.

Wang, M.Q., 1994. Cost savings of using a marketable permit system for regulating light duty vehicle emissions. Transport Policy, 1: 221-232. 